\title{
TINJAUAN GEOGRAFIS “LITORALISASI” DI KAWASAN PESISIR SELATAN YOGYAKARTA
}

\author{
Triyono \\ Pusat Riset Wilayah Laut dan Sumber Daya Non Hayati \\ Badan Riset Kelautan dan Perikanan \\ Jl. Pasir Putih I Ancol Timur Jakarta \\ E-mail: triyono_dkp@yahoo.co.id
}

\begin{abstract}
"Littoralization" can be geographically studied based on geomorphological approach and landuse system. The method of coastal geography provides useful data of geomorphology and landuse system. This research was conducted in the coastal area of south of Yogyakarta. To process spatial data was used Geographic Information System (GIS) methods (i.e. Aerial photography, satellite imagery, and field observation results). The results showed that the research area has a volcanic sandy coastal typology with flat to sloping topography. Further, this typology is divided into three units of typology, the active beach ridge and sand dunes, non active beach ridge, and the foot hills. Development of the settlements tends toward the sea due to economic dependence on beach tourism.
\end{abstract}

Keywords: littoralization, coastal geography, coastal typology, settlement development

\section{PENDAHULUAN}

Sejak dikenalnya transportasi maritim dan kolonialisasi, pesisir menjadi pendukung utama berbagai aktivitas manusia. Perkembangannya pemanfaatan lahan pesisir semakin intensif, baik untuk kegiatan ekonomi maupun sebagai tempat tinggal. Kebutuhan akan lahan mendorong manusia menempati lahan pesisir hingga ke perbatasan antara darat dan laut yang merupakan daerah rawan bencana. Perkembangan pemanfaatan lahan pesisir ini disebut litoralisasi laut (El Mrini et al., 2008).

Penelitian litoralisasi banyak dilakukan di Perancis karena adanya fenomena semakin tertariknya penduduk untuk menempati dan beraktivitas di kawasan pesisir. Salah satu kekhawatirannya adalah, seperti tempat-tempat yang lain, pesisir Perancis mengalami haliotropisme dan semakin padatnya pemukiman yang berevolusi spasial dan temporal heterogen. Di sisi lain, perkembangan pemukiman dan eksploitasi intensif ruang pesisir menciptakan situasi berisiko laut (MeurFerec C, 2006). Geografi pesisir (Coastal Geography, géography du littoral) mempelajari ruang yang secara spesifik merupakan hasil kerja alam, yaitu keberadaan kawasan pertemuan laut-darat hingga kontak antara hidrosfer laut dan litosfer yang ada di permukaan ${ }^{2}$. Menurut Corlay (1995), untuk melakukan penelitian litoralisasi dengan pendekatan geografi pesisir maka pesisir harus dipahami sebagai sebuah sistem dengan unsur-unsur ganda tetapi memiliki 
dua unsur dasar, yaitu ekosistem dan sosiosistem, kombinasi faktor-faktor yang relevan dengan masyarakat, dinamika alam dan dinamika sosial. Peran pendekatan geografi pesisir dalam pengelolaan kawasan pesisir diterapkan melalui zonasi kawasan pesisir berdasarkan karakteristik geografinya.

Penelitian mengenai litoralisasi penting dilakukan di Indonesia mengingat pusat-pusat permukiman dan aktivitas ekonomi berada di kawasan pantai dan pesisir, sedangkan pantai dan pesisir Indonesia merupakan kawasan yang rawan bencana laut. Selama ini, belum banyak penelitian mengenai litoralisasi di Indonesia. Kota-kota besar di Indonesia sebagian besar berada di kawasan pesisir. Semakin berkembangnya kota, kawasan pantai menjadi pilihan sebagai tempat bermukim dan beraktivitas ekonomi, baik kegiatan perikanan, industri, maupun pariwisata.

Kawasan pesisir Parangtritis, Yogyakarta sebagian besar berupa pantai dari akumulasi pasir endapan gunung api. Topografi yang relatif datar menjadikan kawasan pesisir ini menarik untuk dibudidayakan dan ditinggali oleh penduduk. Beberapa segmen pesisir selatan tersebut dimanfaatkan untuk aktivitas pertanian, pariwisata dan lahan permukiman. Kunjungan wisatawan di pantai ini pada bulan Desember tahun 2004 melampaui 250.000 orang (Dinas Pariwisata, 2007). Perkembangan kawasan wisata yang ditandai oleh peningkatan jumlah wisatawan menyebabkan ketertarikan penduduk untuk membangun usaha dan bermukim di Parangtritis. Menurut Ritohardoyo (2007) perkembangan kualitas dan kuantitas permukiman bervariasi secara keruangan. Semakin banyaknya permukiman yang cenderung menuju ke laut, menyebabkan kawasan permukiman Parangtritis rentan bencana alam asal laut.

Tujuan penelitian ini adalah mengkaji litoralisasi dan tipologi pantai yang diharapkan bermanfaat bagi pengelolaan kawasan pesisir secara terpadu. Selain itu, hasil penelitian diharapkan mampu menambah khasanah teoritis ilmu geografi. Kajian litoralisasi ini mencakup perkembangan pesisir secara fisik geomorfologi dan perkembangan permukiman atau bangunan.

\section{METODE PENELITIAN}

Area penelitian dilakukan di kawasan Parangtritis dan termasuk pesisir selatan Yogyakarta dengan luas sekitar $27 \mathrm{~km}^{2}$. Jarak dari pusat kota Yogyakarta adalah 30 km sedangkan dari pusat Kota Bantul sekitar $10 \mathrm{~km}$. Daerah penelitian adalah pesisir dengan topografi datar hingga bergelombang dan merupakan tipologi pesisir akumulasi endapan vulkanik (Khakhim et al., 2008).

Perkembangan permukiman dan penduduk yang cepat di Parangtritis menarik untuk diteliti, terutama mengenai kecenderungan perkembangannya. Karakteristik fisik kawasan berupa pesisir landai hingga bergelombang dengan material pasir memudahkan untuk perekayasaan permukiman. Posisi yang menghadap langsung Samudera Hindia sudah tentu menimbulkan resiko bencana tersendiri, terutama tsunami yang mungkin terjadi di kawasan tersebut.

Data yang dikumpulkan dalam peniliti ini berupa data primer yang meliputi pengukuran topografi detil interval kontur 1 meter dengan alat RTK, wawancara mengenai kondisi sosial-ekonomi, dan data 
deskriptif pengamatan bentukan-bentukan alam. Analisa spasial permukiman dilakukan melalui interpretasi foto udara dan citra satelit multi temporal. Analisis data primer didukung oleh adanya data sekunder yang berupa data-data statistik demografi dan hasil-hasil penelitian terdahulu.

Langkah-langkah penelitian yang dilakukan menurut tahap-tahap: (1) penelaahan kepustakaan tentang delineasi kawasan pesisir dan identifikasi geomorfologi kawasan, (2) mempelajari karakteristik daerah yang meliputi geomorfologi, iklim, dan sumberdaya, (3) survei lapangan pengukuran topografi kawasan dan penggunaan lahan aktual, dan (4) menelaah karakter fisik dan sosial kawasan untuk analisis tipologi pesisir.

Pemetaan karakteristik kawasan pesisir berdasarkan pendekatan geomorfologi dengan satuan pemetaan adalah satuan medan (terrain unit) pada skala detil. Penelitian mengenai karakter fisik Parangtritis dilakukan melalui analisa penginderaan jauh (Gambar 1). Hasil interpretasi citra satelit ini kemudian ditumpangsusunkan dengan hasil pengukuran topografi detil di lapangan untuk mengklasifikasikan kelas kemiringan lerengnya.

Analisis tipologi pantai meliputi kriteria geomorfologi berupa kemiringan lereng, jenis material, dan proses yang dominan yang berada pada zona antara perairan surut dan pasang tinggi dan ruang yang masih dipengaruhi oleh laut. Proses geomorfologi yang menyebabkan perkembangan pesisir diidentifikasi melalui tumpangsusun (overlay) peta-peta topografi daerah penelitian yang memiliki tahun pembuatan berbeda dengan bantuan perangkat lunak Geographical Information
System (GIS) ArcGIS 9.2. Tipologi pantai dianalisis melalui interpretasi citra satelit ASTER (Advanced Spaceborne thermal Emission and Reflection Radiometer) orthorectified dianalisis dengan algoritma klasifikasi unsupervised mengkombinasikan saluran ASTER VNIR RGB: 3N-2-1. Perangkat lunak yang digunakan adalah ENVI 4.3.

Kriteria sosial-ekonomi kawasan meliputi aktivitas penduduk di kawasan pesisir yang tergantung pada kegiatan darat dan laut. Perkembangan penduduk dikaji berdasarkan statistik dan laporan resmi Pemerintah. Wawancara dan pengamatan di lapangan dilakukan untuk memperoleh data kriteria sosial ekonomi. Perkembangan permukiman dianalisis melalui interpretasi foto udara multi temporal tahun 1960, 1992, 2000, 2002, 2003, dan citra satelit Quickbird tahun 2006. Bangunan didelineasi secara manual dengan ArcGIS 9.2. Dengan melakukan tumpang susun hasil interpretasi bangunan diperoleh perkembangan bangunan antar waktu.

Analisa karakteristik geografi kawasan sebagai refleksi daya dukung lingkungan diolah dan disajikan secara tabulasi dan spasial melalui peta. Metode analisis yang digunakan dalam penelitian ini adalah metode deskriptif didukung dengan metode kualitatif untuk data sosial demografi.

\section{HASIL DAN PEMBAHASAN}

\section{Tipologi pesisir}

Berdasarkan pada interpretasi peta topografi multitemporal dan citra satelit, diperkirakan besarnya kemajuan lahan (progresi) ke arah laut sekitar 165 meter garis pantai Parangtritis, selama periode tahun 1919 hingga 2001. 


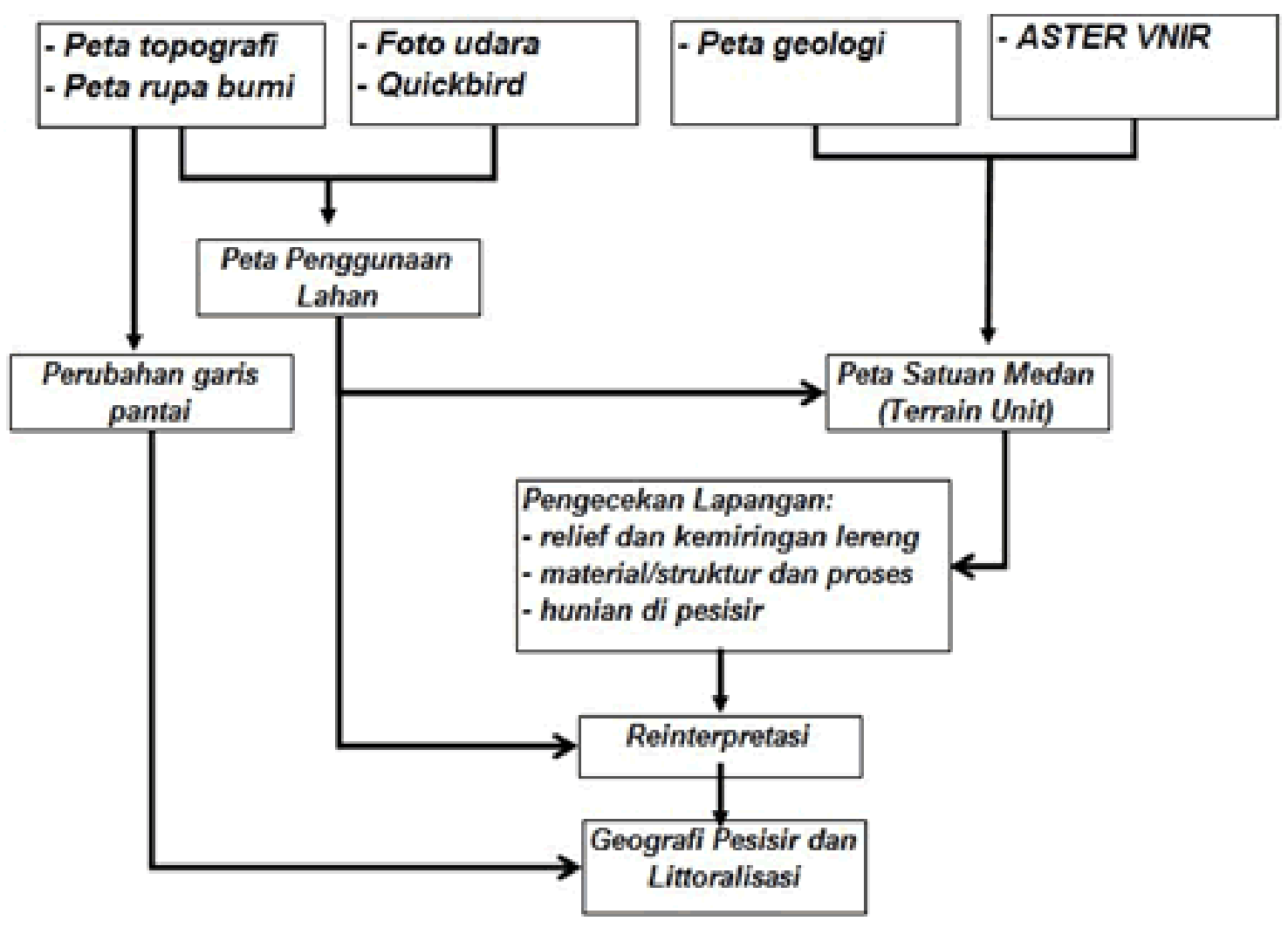

Sumber: Corlay et al., 1995 dengan modifikasi

Gambar 1. Alur Penelitian Litoralisasi di Parangtritis

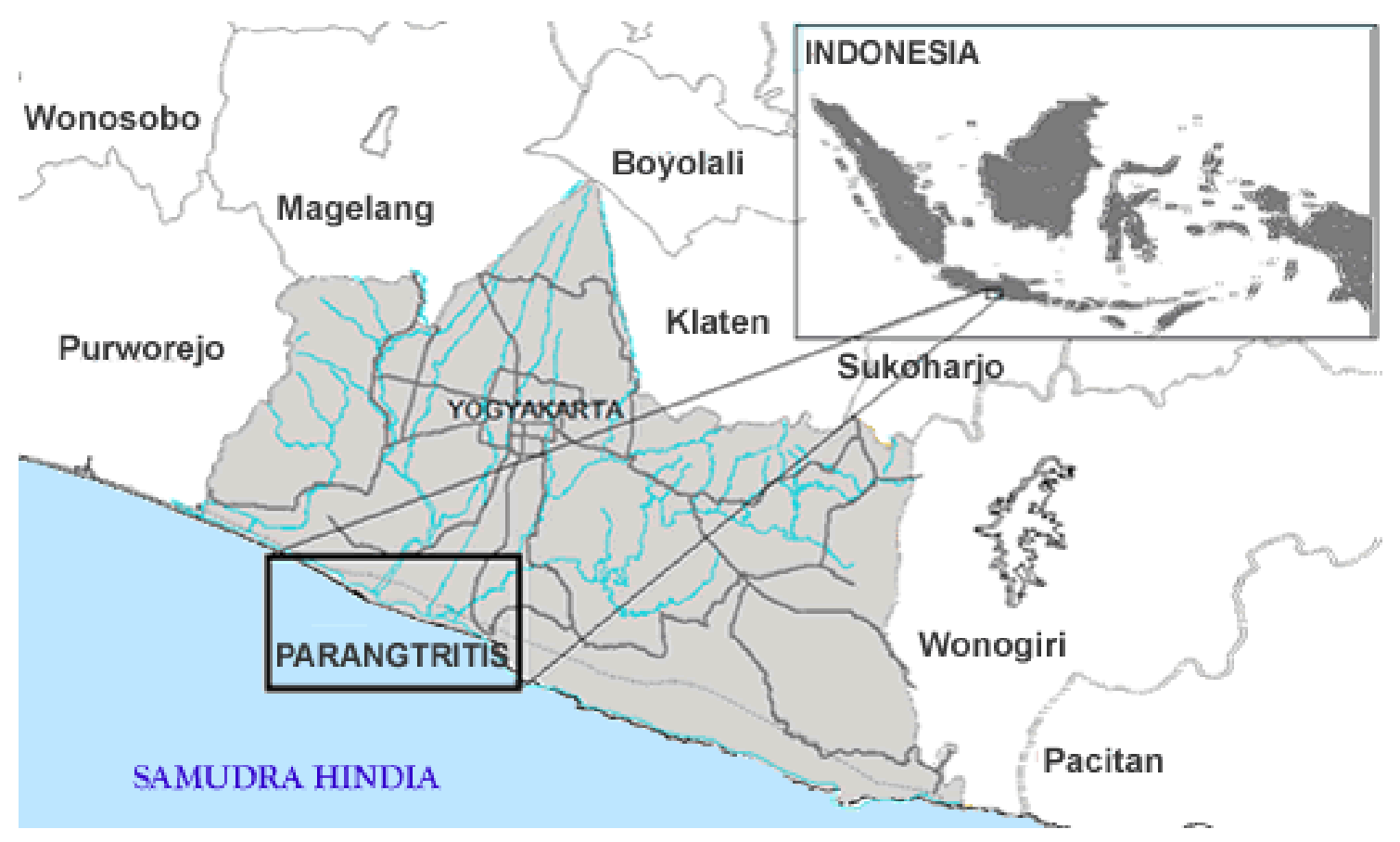

Sumber: Peta Rupa Bumi Indonesia (RBI) Skala 1: 25.000

Gambar 2. Lokasi Penelitian Pantai Parangtritis 
Progresi besar terjadi antara 1919 hingga 1944 (sekitar 1,6 meter per tahun) dan terbesar ketika terjadi pada tahun 1944 hingga 2001 atau sekitar 2,2 meter per tahun (Gambar 3). Situasi ini menggambarkan bahwa pesisir Parang-tritis mengalami kemajuan akibat sedimentasi membentuk tipologi pantai berpasir vulkanik datar hingga miring (Gambar 4).

Dengan melakukan analisis tiga dimensi melalui perangkat lunak GIS antara hasil delineasi interpretasi geomorfologi citra ASTER dengan hasil pengukuran lapangan, diperoleh tiga satuan tipologi pantai Parangtritis, yaitu: 1) gisik aktif datar hingga landai material pasir vulkanik $(25 \%), 2)$ gisik non aktif landai bergumuk material pasir vulkanik (59,5\%), dan 3) kaki perbukitan landai hingga miring material campuran pasir dan koluvial (15\%). Hasil interpretasi menunjukkan bahwa topografi pesisir Parangtritis tidak seragam dengan adanya tiga cekungan. Lokasi-lokasi cekungan juga merupakan daerah rentan terhadap genangan air laut.

Kawasan pesisir pantai selatan Yogyakarta merupakan kawasan pesisir yang terus mengalami kemajuan akibat adanya sedimentasi. Tenaga geomorfologi laut berupa arus pasang surut dan hempasan ombak membentuk tipologi pantai gisik aktif yang kemudian dengan adanya tenaga angin mengangkut pasir kearah belakang

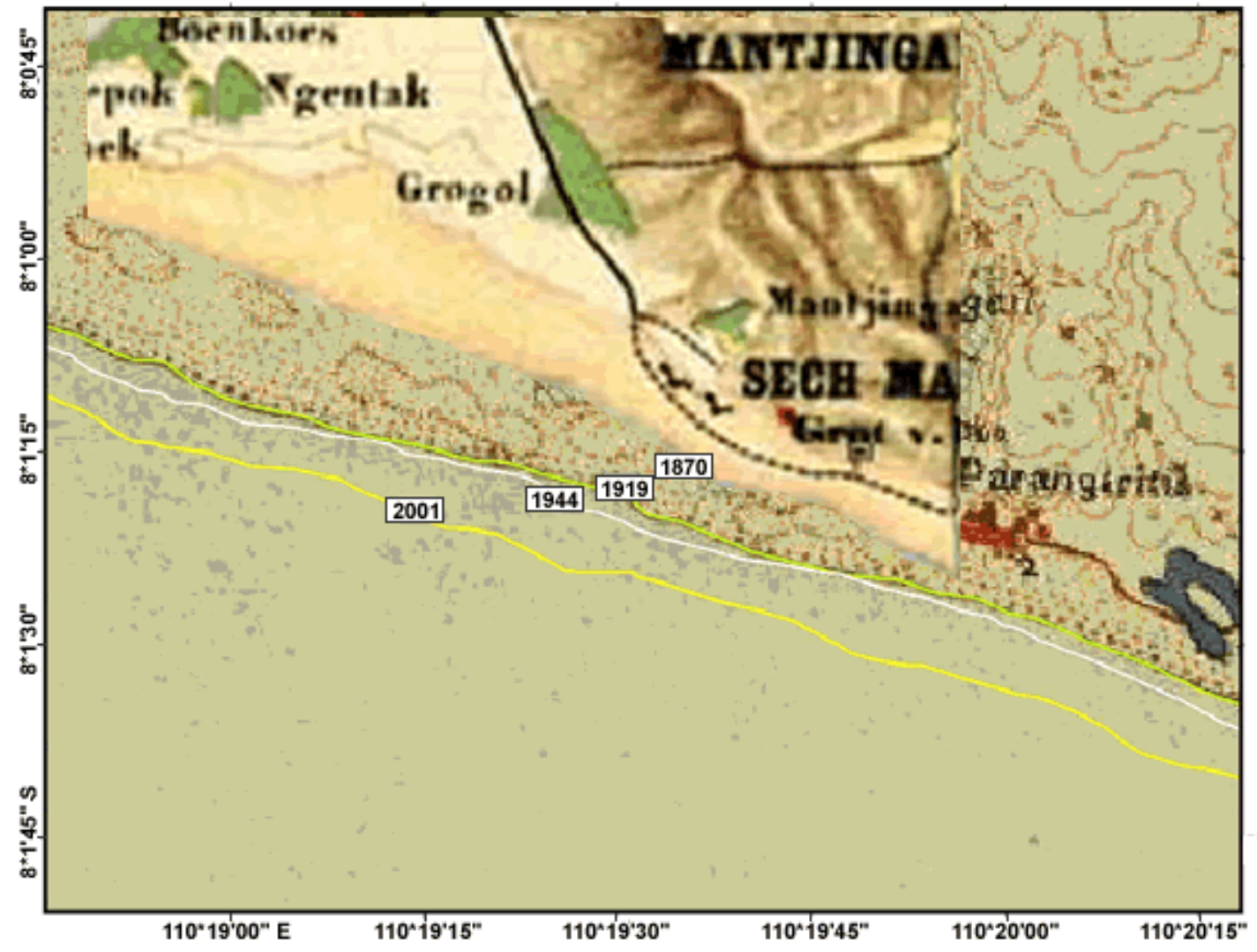

Sumber: Peta Rupa Bumi Indonesia (RBI) Skala 1: 25.000

Gambar 3. Perkembangan Garis Pantai Parangtritis 


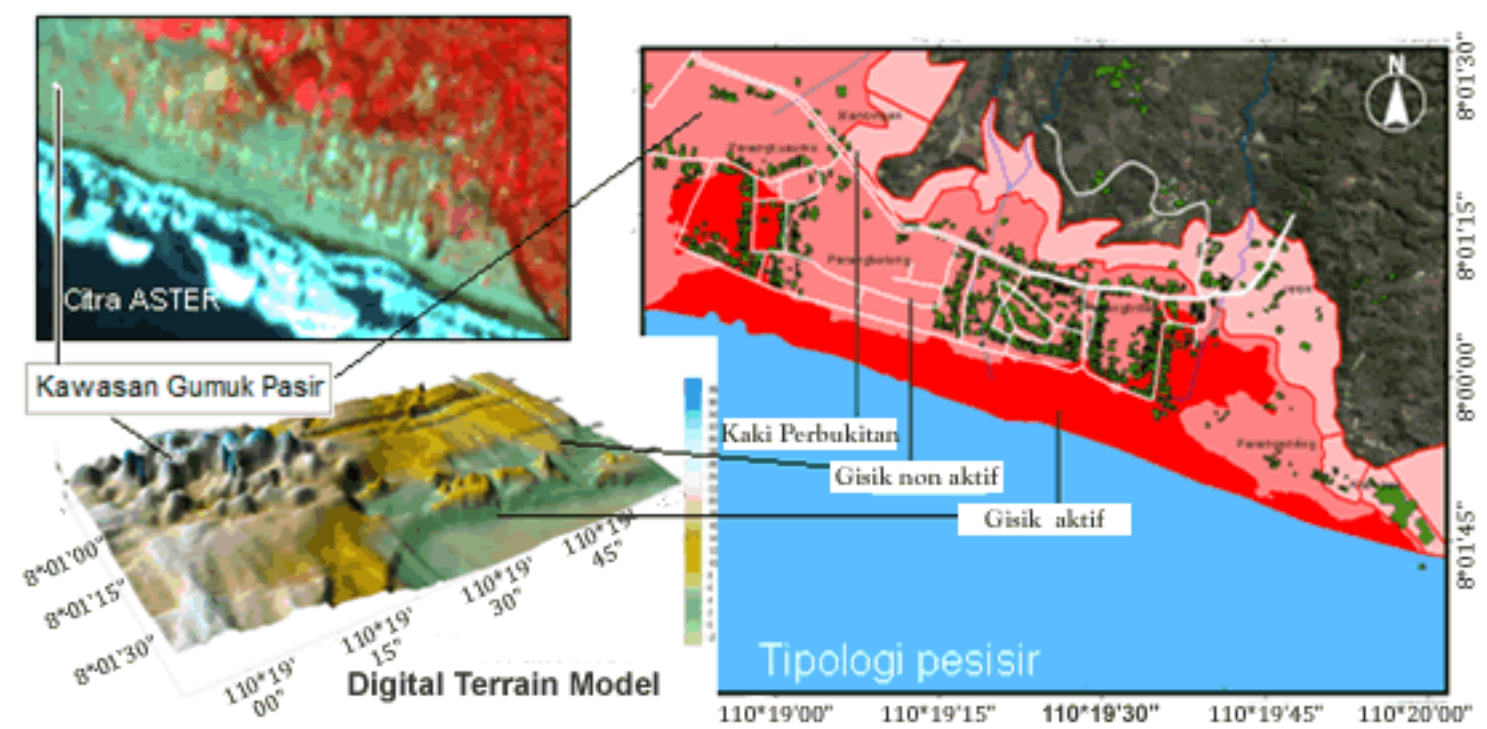

Sumber: Hasil Analisis Citra Digital

Gambar 4. Tipologi Pantai Lokasi Penelitian

membentuk gisik non aktif dengan gumukgumuk pasir. Pantai gisik aktif berhadapan langsung dengan hempasan ombak/ gelombang sehingga sangat labil dan dapat mengalami perubahan letak, baik kedepan (progresif) maupun mundur (regresif). Ratarata lebar dari pantai gisik aktif antara 10 meter hingga 20 meter. Di belakang pantai gisik aktif terbentuk pantai gisik non aktif seiring semakin kecilnya peran energi hempasan ombak/gelombang. Gumuk pasir terbentuk jauh belakang pantai gisik non aktif.

Satuan gisik aktif merupakan kawasan yang sangat terbuka terhadap bencana karena berhadapan langsung dengan laut, sedangkan kawasan belakangnya relatif aman dari ancaman bencana tersebut. Beting gisik aktif merupakan kawasan yang pada saat pasang tinggi dapat tergenang oleh air laut. Material pantai pada saat kering terangkut oleh tenaga angin. Pada Gisik non aktif, proses geomorfologi ini tidak terjadi, kecuali untuk transport ma- terial pasir oleh angin. Kaki perbukitan merupakan kawasan yang cukup jauh dari pengaruh laut dan merupakan kawasan yang cukup aman terhadap tsunami.

\section{Perkembangan permukiman}

Daya tarik wisata pantai menyebabkan semakin berkembangnya aktivitas ekonomi yang berdampak pada semakin berkembang-nya permukiman di sekitar pantai. Pada tahun 1960-an hanya terdapat sekitar 20 Kepala Keluarga (KK) yang bermukim di kaki bukit dan Pegunungan Seribu. Namun, hingga tahun 2000 tercatat sebanyak 1.098 rumah di kawasan tersebut. Kawasan gumuk pasir banyak mendapatkan tekanan bangunan dilihat dari pertumbuhan bangunannya yang berkembang sejajar dengan pantai dan berhadapan dengan laut. Dari tahun 1960 hingga tahun 2006 terjadi peningkatan jumlah bangunan secara sangat signifikan, yaitu $3.600 \%$ dan diringi oleh pertumbuhan 
penduduk (Gambar 4). Perkembangan ini dimulai sejak selesainya pembangunan Jembatan Kretek yang menghubungkan Parangtritis dengan Kota Bantul dan Yogyakarta (Sudaryono et al., 2002).

Secara spasial, perkembangan permukiman ini mengarah ke pantai mendekati
Sekitar 21,5\% permukiman berada di gisik aktif dan 64\% berada pada gisik non aktif. Perkembangan permukiman ini sangat terkait dengan aktivitas pariwisata yang berkembang di Parangtritis yang dapat dilihat dari struktur umur penduduk pesisir Parangtritis yang sebagian besar usia produktif.

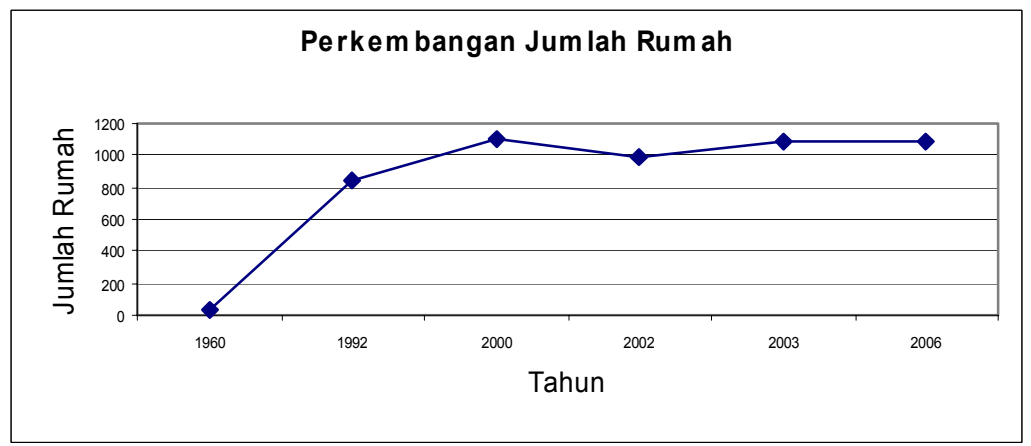

Sumber: BAPPEDA Bantul, 2006

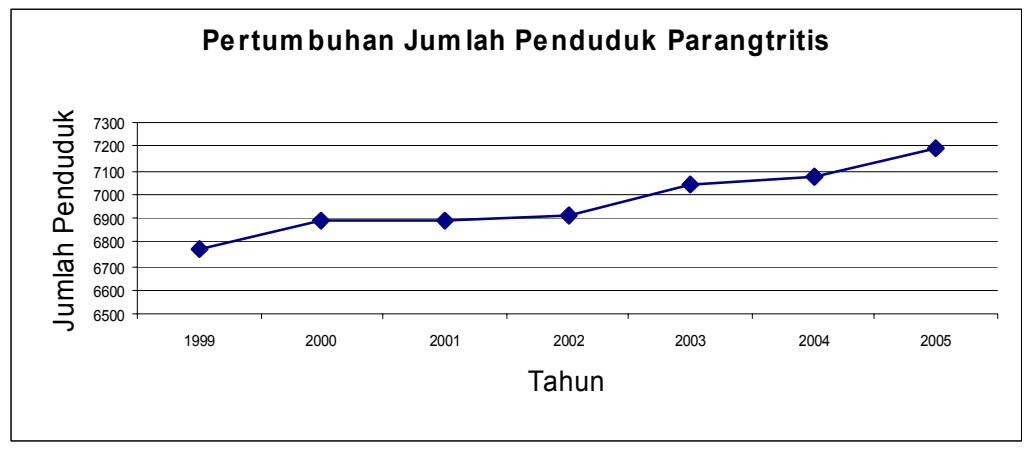

Sumber: BAPPEDA Bantul, 2006

Gambar 4. Dinamika Bangunan dan Pertumbuhan Penduduk Parangtritis

lokasi wisata pantai, berawal dari kaki perbukitan menuju beting gisik aktif. Perkembangan permukiman kearah laut ini menyebabkan semakin berkembangnya permukiman ke arah pantai dengan pusatpusat perkembangan merupakan obyekobyek wisata utama di kawasan Parangtritis yaitu: Parangkusumo, pemandaian air hangat, makam, dan plasa Parangtritis. Perkembangan permukiman kearah pantai dapat meningkatkan keterbukaan permukiman terhadap resiko bencana laut.

\section{Sosial ekonomi}

Jumlah penduduk Desa Parangtritis pada tahun 2005 adalah 3.489 jiwa, dengan kepadatan penduduk 606 jiwa $/ \mathrm{km}^{2}$. Tingkat kesejahteraan mereka pada umumnya adalah menengah, dan pendapatan mereka umumnya berasal dari aktivitas pariwisata. Pendapatan minimum rumah tangga Indonesia adalah Rp. 715.000/bulan (Triyono, 2008). 


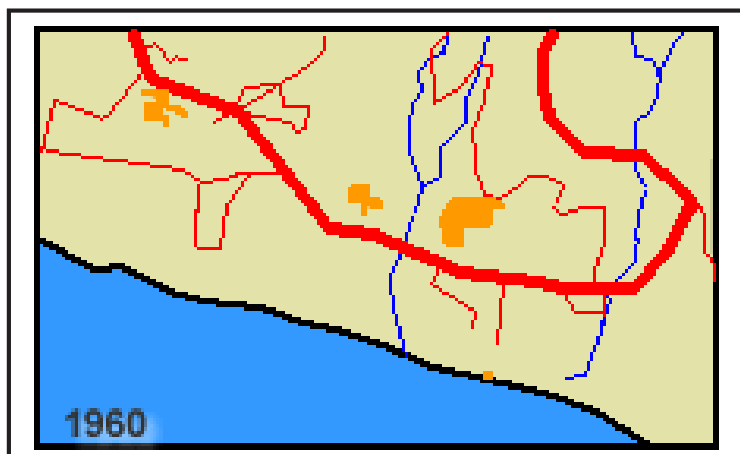

a. Sebaran Permukiman Tahun 1960

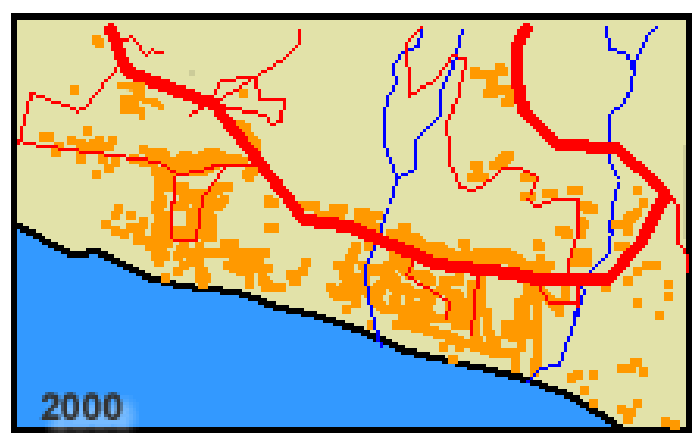

c. Sebaran Permukiman Tahun 2000

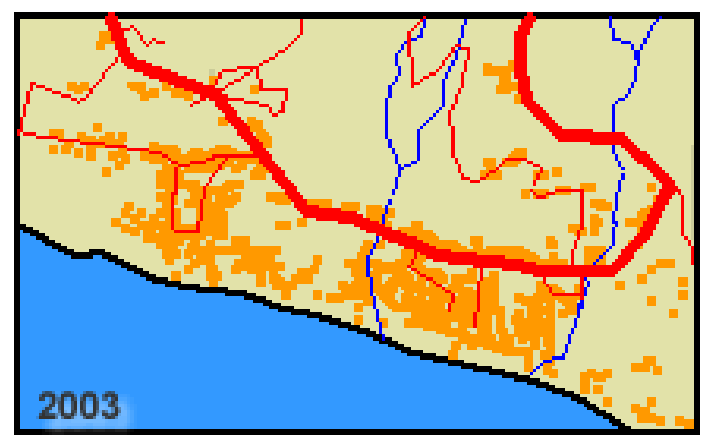

e. Sebaran Permukiman Tahun 2003
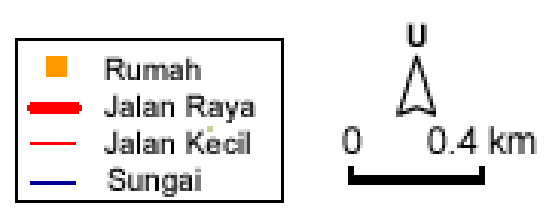

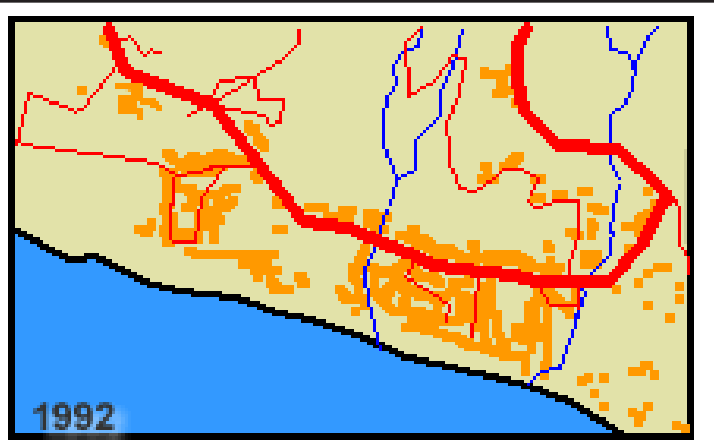

b. Sebaran Permukiman Tahun 1992

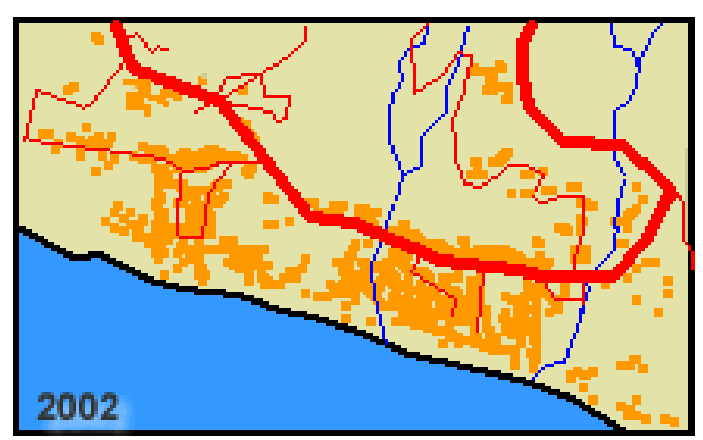

d. Sebaran Permukiman Tahun 2002

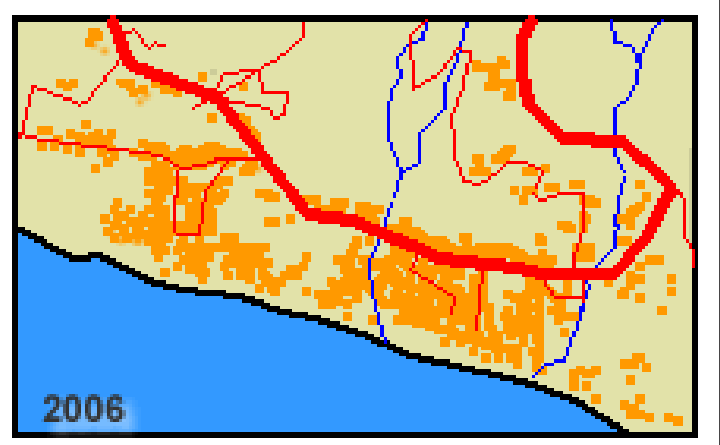

f. Sebaran Permukiman Tahun 2006

Sumber:

Foto Udara Tahun 1960, 1992, 2000, 2002, 2003

Citra Quick Bird 2006

Gambar 5. Arah Perkembangan Permukiman Tahun 1960 - 2006 
Berdasarkan data statistik Desa Parangtritis tahun 2007, kawasan pesisir ini dihuni oleh sebagian besar penduduk usia produktif (15 - 56 tahun). Ini menunjukkan bahwa ketergantungan ekonomi masyarakat terhadap aktivitas ekonomi kepariwisataan sangat tinggi. Data statistik hasil survei menunjukkan bahwa 64\% penduduk berprofesi sebagai pemilik rumah makan/ warung (Bappeda Bantul, 2006).

\section{KESIMPULAN}

Kawasan Parang tritis terbagi menjadi tiga tipologi pesisir dengan dominasi material pasir vulkanis Gunung Merapi. Perkembangan pesisir kearah laut dan berkembangnya pariwisata menyebabkan penduduk semakin tertarik untuk tinggal di kawasan pesisir. Pantai gisik aktif berhadapan langsung dengan samudera Hindia, pantai gisik non aktif dengan gumuk pasir berada di belakangnya, dan kaki perbukitan di formasi paling belakang. Tipologi pesisir Parangtritis memiliki pola paralel memanjang berarah timur- barat, paralel dengan garis pantai.

Fenomena litoralisasi banyak ditemukan di pesisir Indonesia sebagai kecenderungan pemanfaatan lahan pesisir. Kawasan pesisir Parangtritis sebagai contoh litoralisasi dikaji untuk dapat diterapkan di seluruh pesisir Indonesia dengan memperhatikan karakter fisik, sosial ekonomi, dan penggunaan lahan.

\section{UCAPAN TERIMA KASIH}

Penulis mengucapkan terima kasih kepada Fakultas Geografi Universitas Gadjah Mada, khususnya kepada Dr. Junun Sartohadi, M.Sc, dan kepada PUSPICS UGM atas data foto udara dan citra ASTER, penulis juga sangat berterima kasih kepada Prof. Catherine Meur-Ferec dan Dr. Alain Hennaf dari Institut Universitaire Européen de la Mer UBO-France atas bimbingan metodologi kajian géographie du littoral.

\section{DAFTAR PUSTAKA}

Bappeda Bantul. 2006. Data Pokok Kabupaten Bantul, Pemerintah Kabupaten Bantul.

Corlay, Jean-Pierre. 1995. Géographie Sociale, Géographie du Littoral, Norois, Poitiers, e. 42, $n^{\circ} 165$, p. $247-265$.

Dagnelie, Pierre. 1998a. Statistique Théorique et Appliquée, Tome 1: Statistique descriptive et bases de l'inférence Statistique, De Boeck Université.

Dagnelie, Pierre. 1998b. Statistique Théorique et Appliquée, Tome 2: Inférence Statistique à une et à deux dimensions, De Boeck Université.

Dahuri, H. Rochmin, Jacob Rais, Sapta Putra Ginting. 2001. Pengelolaan Sumberdaya Wilayah Pesisir dan Lautan Secara Terpadu, Jakarta: Pradnya Paramita. 
Dauphiné A.. 2003. Risque et Catastrophe : observer, spatialiser, comprendre, gérer, Armand Collin, p288

Dinas Pariwisata. 2007. Data Statistik Pariwisata Kabupaten Bantul, Pemerintah daerah Kabupaten Bantul

Dumolard P., Dubus N., Charleux L.. 2005. Les Statistiques en Géographie, Belin, Paris Cedex

El Mrini A, Nachite D., Taaouati M.. 2008. Interactions Physico-Naturelles Et Socio-Economique Sur Le Littoral Tetonanais (Maroc Nord Occidental), Actes du colloque international pluridisciplinaire "Le littoral : subir, dire, agir" - Lille, France, 16-18 janvier 2008

Khakhim, Nurul, Dedi S., Ani M., Vincentius P. S., Mennofatria B. . 2008. Analisis Visual Lanskap Pesisir Daerah Istimewa Yogyakarta untuk Pengembangan Pariwisata Pesisir Menuju pada Pengelolaan Wilayah Pesisir Berkelanjutan, Forum Geografi Volume 22 No. 1 Juli 2008.

Lavigne, F., C. Gomez, M. Gifo, P. Wassmer, C. Hoebreck, D. Mardiatno, J. Priyono, and R. Paris. 2007. Field Observations of the 17 July 2006 Tsunami in Java, Natural Hazard and Earth System Science, 7(1), 177 - 183

Meur-Ferec C.. 2006. De la Dynamique Naturelle à La Gestion Intégrée de L'espace Littoral: Un Itinéraire de Géographe; Volume 1 - Essai Inédit, Document présenté en vue de l'habitation à diriger des recherches, Université de Nantes

Meur-Férec C. et Morel V.. 2004. L'érosion sur la frange côtière: un exemple de gestion des risques. Nature Science et Société 12, 263-273

Puspito N.T.. 2004. Tsunami Zoning for Southern Coast of Java, Prosiding Himpunan ahli Geofisika Indonesia, 2004

Ritohardoyo, Su. 2007. Perubahan Permukiman Pedesaan Pesisir Kabupaten Gunung Kidul Daerah Istimewa Yogyakarta Tahun 1996-2003, Jurnal Forum Geografi Volume 21 No. 1 Juli 2007.

Rynn J. 2002. A Preliminary Assessment Of Tsunami Hazard And Risk In The Indonesian Region, Centre for Earthquake Research in Australia

Sudaryono, Purbadi .J, Hardiyanto, Srisulistyani, Triyono, Arif A.. 2002 - 2004. Karakter Ruang Lokal Sebagai Mainstream Perencanaan Pembangunan Lokal:Upaya Menyumbang Pendekatan dan Substansi Teori Lokal untuk Pembangunan Lokal, Riset Unggulan Bidang Kemasyarakatan dan Kemanusiaan RUKK III, Kantor Menteri Negara Riset dan Teknologi

Triyono. 2008. Evaluation de la Vulnerabilité au Tsunami dans la Région de Bantul, secteur de Parangtritis en Indonesie :Mémoire Master 2, Institut Universitaire Européen de la Mer, Université de BRETAGNE OCCIDENTAL, Perancis

Yalçiner A.C., Pelinovsky E.N., Okal E, Synolakis C.E., (ed). 2001. Submarine Landslide and Tsunamis, NATO Science Series, Earth and Environmental sciences, p.328 